\title{
The Effects of Educational Applications on the Development of Information in Secondary Schools During A Pandemic
}

\author{
Litfulla Ebror Murkhuja ${ }^{1}$, Tureacv Kholiqov ${ }^{1}$, Egor Yuldashev ${ }^{1}$ \\ Email: ebror.khuja1092@gmail.com \\ ${ }^{1}$ Jizzakh State Pedagogical Institute, Uzbekistan
}

\begin{abstract}
Using instructional apps is one of the responses educators and schools have made in response to the Covid-19 pandemic's circumstances, with the aim of continuing the learning phase even though there is no face-to-face instruction at school. As instructional apps such as google classes, zoom meetings, and others are used, they have a huge effect on students' abilities and skills growth, such as slowing the rate of progress in students' comprehension of information. This is motivated by the fact that teachers and students engage infrequently throughout the teaching and learning period. Numerous student topics need face-to-face time in classes such as athletic activity, lab, and art practice. Certain aspects of these activities are hindered by the absence of direct practice in schools as a result of pandemic conditions that force teachers and students to remain at home and ensure a safe distance. Apart from that, utilizing learning apps enables students to begin accepting topics from their inner instructor, requiring both students and instructors to be more innovative with their teaching and learning processes.
\end{abstract}

Keywords: Educational Applications, Teacher and Student Awareness Creation, and Imagination

Received: February 28, 2021

Revised: March 27, 2021

Accepted: April 18, 2021

\section{Introduction}

Education has also been significantly impacted, and in order to halt the transmission of the corona virus, both students and instructors are required to conduct teaching and learning activities from home, which are carried out abruptly and without notice. The unpreparedness among all educational components is indeed a significant impediment (Coe et al., 2014; Blouin \& Perry, 2009). There has been a shift in the method of teaching and learning from face-toface to online classes using applications that need readiness on the part of all stakeholders, including the government, schools, teachers, students, and parents. It is acknowledged that the government relaxes the education assessment system during times of crisis as long as learning will continue without jeopardizing the achievement of competativeness. As a result, often instructors conduct online instruction with the use of current technologies.

Four "actors" play their assigned roles: parents, pupils, staff, and the neighborhood. In terms of potential plans, schools should take five steps, including updating the learning objectives to be accomplished and rationally aligning them with the current circumstances and conditions of the new normal. Identification of the capital that must be acquired and maintained in order to meet the new priorities outlined within the constraints of available resources. Create a map of each teacher's and student's situation and readiness to adopt a modern learning style focused on integrated learning as planned. Assess the difference between need and supply and outline the urgent strategic and organizational measures necessary to close it. Carry out these moves dynamically and innovatively by forming a variety of relationships with external stakeholders that care about education. 
All forms of education become erratic, especially in rural areas. The learning that would be conducted is also unsure how to proceed, but at the moment, the learning was conducted by assigning tasks to children who were contacted through Whatsapp (WA). Additionally, madrasah leaders do not place an undue pressure on teachers and students to attain KD in learning. He was also cautioned during that period of learning not to link COVID-19 values. With the small network offered for free by the government, the author was unable to use madrasa education apps such as e-learning. Since many have links to these learning applications and other applications, the author was unable to apply technology such as Google Classroom, Zoom, and others. Thus, the barriers for teachers whose areas are not yet connected to the internet, or whose learning applications are still in their infancy, make it impossible for teachers to impart information to their students.

To give greater consideration to the survival of this educational world, in order to predict potential events and ensure that this educational framework operates smoothly. Will online learning teach students in this age of the COVID-19 pandemic, or is it the other way around, designed to deceive students? Numerous parents and grandparents have expressed concern for our child's future. Meanwhile, even though we speak face to face, our children struggle to understand, especially through WA, which is sent to our children daily, and we even struggle to understand the classes, such as algebra, let alone English. Not to mention the protests regarding the high cost of internet quotas (data packages), notwithstanding the fact that the rural economy is based entirely on rubber, oil palm, river stone, and rice fields. Both of which are insufficient to cover the students' parents' profits. Thus, some parents of students argue that online education should be discontinued because it serves only to fool their children; they argue that it is preferable for their children to return to madrasah rather than study at home. However, schooling in Uzbekistan is controlled by the nation, and regions of red, yellow, or orange zones do have online learning. Both players in education are only to carry out and adhere to current procedures.

\section{Application of educational software}

After the start of the Covid-19 emergency time, almost all schools in Uzbekistan, especially those that provide online learning or what is known as distance learning, have implemented policies governing online learning or what is known as distance learning. Via online education, both teachers and students gain an understanding about how to utilize technology as a tool for learning.

Online learning must be implemented with different limited skills, equipment, and resources in the form of cellphones, computers, and networks for teachers and students, as well as limited abilities in the application of technology, to ensure that the mechanism of information transformation to students is not disrupted (Bonk \& Zhang, 2008; Eteokleous-Grigoriou, 2009).

Teachers, as the educational leader, take numerous initiatives such as introducing distance learning through Whatsapp Groups, Google Classroom, Moodle, and other online learning applications. Additionally, the trainer utilizes synchronous learning tools such as Google Meet, Zoom Cloud Meeting, and Cisco Webex. There are many free learning opportunities and science content available on the internet at the moment.

Utilization of a variety of distance learning media that are processed according to the teacher's capabilities and preferences. The teacher's requirements are not only academic in nature, but also include the ability to interact effectively, which is needed in distance learning As through Google Classroom, Moodle, and Whatsapp community learning media, teachers submit learning resources, instructional video links, and assignments to students, as well as use it as a contact tool for method feedback and assistance. 


\section{Constraints that students face while using educational applications}

The same obstacles that students encounter in distance learning still arise for instructors, such as a lack of an Android smartphone, data kit, and signal network. These impediments may become impediments throughout the learning phase. However, the instructor knows this condition and offers answers to the issues encountered by students, allowing students to continue with the learning process. When environments are stable and hygiene guidelines are followed, tasks can be taken and collected in school. By allowing for a longer loading period, you may avoid network or signal disruption.

With many constraints in the Covid 19 pandemic case, it's difficult for an instructor to maintain an interest in and practice of online learning. Additionally, teachers must be prepared to present engaging and creative learning in order to address common learning challenges and collaborate with learning media in order to keep learning interesting and maintain an immersive learning environment between teachers and students.

Sport-specific education and classroom practicums are often overlooked (Martin et al., 2010).. Even if the topic educates students and encourages them to develop positive characteristics such as being systematic, attentive, trustworthy, cautious, not giving up easily, and appreciating the method. What's concerning is that whether this pandemic persists over an extended period of time and online schooling is implemented for a complete year or even longer, the nation's youth may become accustomed to a variety of facilities that are not instructional or mature. They risk losing a whole year of character formation, which is extremely beneficial as a preparation for life. This country is no longer threatened by a scarcity of intelligent citizens in the internet age. Everyone will understand something if they have unlimited access to knowledge. However, reading, far less character teaching, is distinct from literacy. This nation requires a young generation with a strong nature, which can only be developed by character education that encourages teachers as role models for educators and students to emulate. Thus, it is beyond time for the government and all levels of education in Uzbekistan to consider ways to substitute character education, which was forced to be ignored during this pandemic. Avoid allowing the degradation of character education standards to become part of the "modern standard." Thus, we can no longer be surprised as the younger generation loses positive characteristics as a result of our schooling becoming increasingly governed by online learning, which emphasizes information transfer over instilling noble moral values.

That is precisely what this nation requires in order to strengthen its present state of distress.

The Effects of Learning Applications on Students' Levels of Understanding During the Pandemic Period The Covid-19 pandemic has affected every country on the planet. All operations, including school activities, have been suspended to deter the transmission of the Corona virus, it has been roughly three months since all educational operations, from primary to secondary to tertiary, have been performed entirely online, with no face-to-face communication between teachers and students.

Online schooling instantly lets one aware of the internet's enormous promise, which has been underutilized in a variety of areas, including education (Carliner \& Shank, 2016; Breivik \& Gee, 2006; Keane \& Wolpin, 2001; Sayer et al., 2004). Educational programs are not restricted by room or time constraints. They can take place at any time and in any location. Additionally, in an age where no one knows when the pandemic will stop, online education is an utter requirement that all Uzbekistan's society must meet.

However, with any good aspect of something, there must be a detrimental aspect, or at the very least a chance of something bad occurring. While structured instructional practices can still be 
conducted online, due to the fact that teachers and students must learn at home during this pandemic, character education seems forgotten.

Historically, when instructional practices were conducted in classrooms, character instruction took place directly under the direction of the instructor or lecturer. Character education activities may often be conducted explicitly, intensively, often with a measurable progress rate.

Physical education and laboratory practicum was still ignored. Even as the topic educates students and encourages them to develop good character traits such as being systematic, conscientious, trustworthy, cautious, not giving up easily, and appreciating the method. What's concerning is that whether this pandemic persists over an extended period of time and online schooling is conducted for a full year or even longer, the nation's youth generation may become exposed to a variety of facilities that are not instructional or mature. They risk losing a whole year of character formation, which is extremely useful as a preparation for life. This country is no longer threatened by a scarcity of intelligent citizens in the internet age, as it is today. Unrestricted access to databases enables us to understand something. However, reading, let alone character teaching, is distinct from literacy. This nation requires a young generation with a strong nature, which can only be developed by character education that emphasizes teachers' examples, which educators and educators must experience and emulate. Thus, it is time for the government and all levels of education in Uzbekistan to consider ways to substitute character education, which was forced to be ignored during this pandemic. Do not allow the lack of ideals associated with character education to become part of the "modern standard." So that we can no longer be surprised as the younger generation loses positive characteristics as a result of our schooling becoming increasingly influenced by online learning, which emphasizes information transfer over instilling worthy moral values.

That is precisely what this nation requires in order to strengthen its own condition, which is already beset by numerous difficulties. The Effects of Learning Applications on Students' Levels of Understanding Throughout the Pandemic Period Now, all countries worldwide are dealing with the Covid-19 pandemic. All practices, including instructional activities, are prohibited to avoid the transmission of the Corona virus. In Uzbekistan, it has been roughly three months after all educational operations, from primary to secondary to tertiary, are performed entirely online, with no face-to-face interaction between teachers and students.

Online schooling quickly alerts one to the enormous promise of the internet, which has been underutilized in a variety of areas, including education. Without regard for room or time constraints, educational events may take place at any time and in any location. Additionally, in an age where no one knows when the pandemic will stop, online education is an utter requirement for all Uzbekistan people.

However, with any good aspect of something, there must be a detrimental aspect, or at the very least a chance of something terrible happening. While structured instructional practices can also be conducted online, because teachers and students are required to learn at home, character education seems a little forgotten during this pandemic.

Historically, when instructional practices took place in classrooms, character instruction took place under the strict guidance of the instructor or professor. Character education activities may often be conducted explicitly, intensively, and their performance rate quantified.

Educational technological advancements are critical in resolving educational issues during the COVID-19 pandemic. Educational technology may facilitate the dissemination of knowledge and the distribution of content, ensuring that learning experiences do not become an impediment, particularly in the case of distance learning. With the features, excitement, and accelerated growth associated with the younger generation / millennials during the COVID-19 
pandemic, educational technology is an active, appropriate, and productive approach for supporting independent learning today.

Educational technology expands the possibilities for self-directed instruction. Educational technologies will help ensure that schooling continues to operate smoothly and aid the government in its attempts to establish physical separation in accordance with health protocols. This is also consistent with the Minister of Education and Culture's directive that all teaching and learning practices be conducted online or through distance learning. The pandemic's influence has also prompted education in Uzbekistan to experiment, developing many educational innovations that facilitate learning and active participation in the fourth industrial revolution. With this urgent situation in mind, the government and academics are developing educational technologies in a variety of forms, including apps, blogs, podcasts, and classrooms, in order to provide an accessible atmosphere for the younger generation / millennials to learn separately.

Utilizing educational technologies when researching separately is one of the current attempts to incorporate cutting-edge technology-based learning platforms in a number of forms and to promote educational technology. Educational technology can also be extremely beneficial and convenient to comprehend in the lives of millennials as a creative learning tool that enables them to quickly access a variety of outlets of information that can be accessed at any time and from any place. This enables instructional technology to have a significant effect on enhancing the independent learning experience and cultivating an open mind about schooling, which is actually only possible by face-to-face or in-person instruction (offline).

\section{Conclusion}

Online learning must be implemented with different limited skills, equipment, and resources in the form of cellphones, computers, and networks for teachers and students, as well as limited abilities in the application of technology, to ensure that the mechanism of information transformation to students is not disrupted. Educational technology expands the possibilities for self-directed instruction. Educational technologies will help ensure that schooling continues to operate smoothly and aid the government in its attempts to establish physical separation in accordance with health protocols. However, where instructional events are conducted electronically and only a learning mechanism or information transmission occurs, nothing will ensure that children or students receive character instruction from their parents in accordance with the principles learned in educational institutions.

\section{References}

Blouin, D. D., \& Perry, E. M. (2009). Whom does service learning really serve? Communitybased organizations' perspectives on service learning. Teaching Sociology, 37(2), $120-135$.

Bonk, C. J., \& Zhang, K. (2008). Empowering online learning: 100+ activities for reading, reflecting, displaying, and doing. John Wiley \& Sons.

Breivik, P. S., \& Gee, E. G. (2006). Higher education in the Internet age: Libraries creating a strategic edge. Greenwood Publishing Group.

Carliner, S., \& Shank, P. (Eds.). (2016). The e-learning handbook: past promises, present challenges. John Wiley \& Sons.

Coe, R., Aloisi, C., Higgins, S., \& Major, L. E. (2014). What makes great teaching? review of the underpinning research. 
Eteokleous-Grigoriou, N. (2009). Instilling a new learning, work and communication culture through systemically integrated technology in education. Systems Research and Behavioral Science: The Official Journal of the International Federation for Systems Research, 26(6), 707-716.

Keane, M. P., \& Wolpin, K. I. (2001). The effect of parental transfers and borrowing constraints on educational attainment. International Economic Review, 42(4), 1051-1103.

Martin, A., Fleming, J., Ferkins, L., Wiersma, C., \& Coll, R. K. (2010). Facilitating and integrating learning within sport studies cooperative education: Exploring the pedagogies employed by students, academics and workplace supervisors.

Sayer, L. C., Gauthier, A. H., \& Furstenberg Jr, F. F. (2004). Educational differences in parents' time with children: Cross-national variations. Journal of marriage and family, 66(5), 1152-1169. 